Review Articles

\title{
A Review of Flood Risk Analysis in Nigeria
}

\author{
Akinola Adesuji Komolafe, Suleiman Abdul-Azeez Adegboyega and Francis Omowonuola Akinluyi
}

Department of Remote Sensing and GIS, Federal University of Technology, Akure, Ondo-State, Nigeria

\section{Article history}

Received: 16-06-2015

Revised: 13-08-2015

Accepted: 20-08-2015

Corresponding Author:

Akinola A. Komolafe

Department of Remote Sensing and GIS, Federal University of

Technology, Akure, Ondo-State, Nigeria

Email: aakomolafe@futa.edu.ng

\begin{abstract}
Nigeria has witnessed diverse flood events in the past years and due to the high level of vulnerability and lack of coping capacity of the people, with the fast occurrence of extreme events resulting from climate change, many lives and properties are at risk of its impacts. This paper reviews the recent past and present efforts in assessing the flood impacts in Nigeria. We concentrate this study on the recent works (methods and results) in assessing flood impacts in the country under basic components of flood risk analysis: The hazards mapping and modeling, exposure and vulnerability assessment, with the aim of suggesting possible urgent needs and further development. Based on our review, we conclude that, there is need to explore more effectively the use of state of the art flood models, which integrates all hydrological processes for more accurate prediction and mapping of flood and its associated risks. Also, as one of the steps to plan for adaptation and mitigation of future flood risk and climate change, there is a serious need of detailed research in the development of regional or national flood damage functions for pre-disaster flood damage estimation. The study also suggests further study on the environmental and health impact of flood in the country.
\end{abstract}

Keywords: Flood, Hazards Mapping, Vulnerability, Exposure, Climate Change, Risk Analysis, Nigeria

\section{Introduction}

Flood is considered to be one the most devastating and frequently occurring natural hazards in the world. Impacts of flood disaster on the society and its effect on sustainable development are overwhelming in recent years. The increasing climate change, accompanied with excessive rainfalls and its devastating consequences remain indelible in the lives of many people and the environment. Over the years and in almost every part of the world, excessive rainfalls due to climate change have resulted in flooding, which has claimed lives and properties. These unpalatable experiences have placed many countries, on hold in their struggle for development. As the world's population increase at an alarming rate with increase in infrastructural development on the rise, more lives and properties are becoming vulnerable to the risk of flood hazards whenever extreme events occur (Dutta et al., 2013; Herath and Wang, 2009; James and Hall, 1986). The devastating effects are recorded in terms of mortality and economic risk by both national and international agencies. Although research claims that the mortality rate is reducing globally due to the established early warning systems in some countries (mostly the developed), but in some localities, especially in the developing and under developed countries, those living in the coastal areas, increasing deaths are witnessed because of their level of exposures and vulnerability.

A close examination of the global disaster databases from EM-DAT for the last three decades (1982-2012) revealed that climatic events (flood, storms, extreme temperature and droughts) accounts for about $69 \%$ of total economic losses globally with flood events causing $25 \%$ of all the total losses (Herath and Wang, 2009). United Nation reports a 35\% increase in flood economic risks, driven by the increasing people's exposure and economic assets experienced in the last decades (UNISDR, 2009a).

In Nigeria, flood accounts for the highest occurring natural hazards, with great consequences on the life and property (Aderogba, 2012). Causes of flood are 
both natural and anthropogenic; the natural causes are basically heavy rainstorm and ocean storms along the coast while the human causes are as a result of burst water main pipes, lack of effective drainage systems, dam failure and spills. Flood in Nigeria is becoming yearly events; it occurs in the form of coastal flood, river flood, flash floods and urban flood. In the last decades for instance, many states and cities have witnessed unusual and devastating flood disasters, which undermined the government's capability to prevent such disasters. Devastating flood events in Nigeria can be dated back to 1963 in Ibadan city, when Ogunpa River was over-flown causing loss of lives and property; these hazardous events reoccurred in 1978, 1980 and 2011, with estimated damages and deaths of over 30 billion naira and 100 people respectively, thus making Ogunpa River nationally and internationally famous (Adegbola and Jolayemi, 2012; Agbola et al., 2012). Between 2011 and 2012 alone, Lagos state recorded at least 8 major floods with more than 30 people deaths and many damages to properties (Editor, 2012; Komolafe et al., 2014). The worst but recent of all the flood events that caused a huge devastation across the geopolitical zones in the country was the July, 2012 event. The flood (the worst since 40years), which occurred in at least 33 states out of the 36 states of the country as a result of a very heavy rainfalls that caused a lot of damages both to lives and properties (UNCHA, 2012). According to EM-DAT: International Disaster Database on Nigeria disaster, in 2012 alone, about 7,000, 867 lives were affected by the widely spread flood while 363 and $\$ 500,000$ deaths and economic damages respectively were recorded (Guha-Sapir et al., 2013) (Fig. 1).
Despite the almost yearly occurrence of flood hazards and the huge risks associated with them, it appears not much works have been done presently on effective management and adaptation to the flood hazards and also on the preparation for potential future hazards. This paper reviews the past and present studies that have contributed to the development, mapping and analyzes of the flood risk in Nigeria by presenting their results, analyzing their methods and providing necessary further and advance research development as compared with global flood risk analysis models.

\section{Flood Risk Analysis: The General Concepts}

In recent years, the world's attention has been shifted from the flood hazard control to flood impacts/risks assessment (Bubeck et al., 2011; Ke et al., 2012). Risk according to the United Nations office of disaster risk reduction (UNISDR) is defined as the combination of the probability of an event and its negative consequences (UNISDR, 2009a; 2009b; 2013a; 2013b). Earlier researchers (e.g., Hewitt, 1980) have put forward that hazards occurrences do not result into disaster and that for actual assessment of the disaster situations and losses, various element such as vulnerability and exposures have to be included (Birkmann, 2013). This has become the basic methods used today in disaster risk analysis. Flood risk therefore is the product of the flood hazards, the vulnerability and the exposure of the people (Bates and De Roo, 2000; UNISDR, 2009b).

Mathematically, risk according to Alexander (2000) and White et al. (2005) can be expressed as:

Total Risk $=$ Hazard $\mathrm{x}$ Vulnerability $\mathrm{x}$

$(\Sigma$ elements at risk $) \ldots \ldots \ldots \ldots \ldots \ldots . . .1$

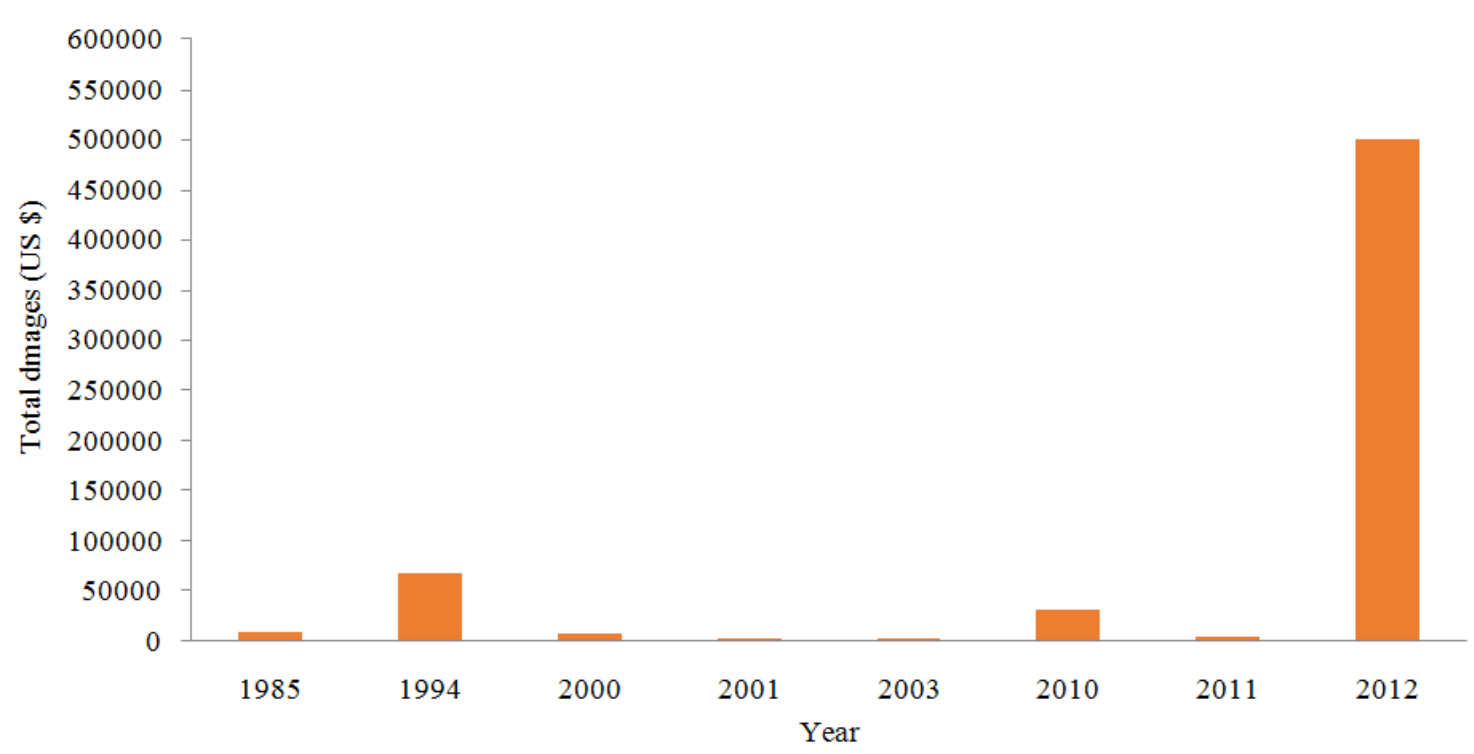

Fig. 1. Flood occurrences and damages in Nigeria between 1985 and 2012 (Source: EM-DAT database) 
This equation is widely used by many researchers to analyze flood risk and potential impacts on the people and community. The first hand of risk at any level and community is the possibility of the occurrence of flood hazards; this however does not result to a negative consequences until the level of the vulnerability and exposures of the people are known. Vulnerability, which is the susceptibility or the degree of chance of the people to the being affected by the potential hazards are of different forms: Physical, social, environmental and economic; these varies within a community and over time (UNISDR, 2009b). It describes the potential to be harmed physically and/or psychologically (White et al., 2005). Exposures on the other hand are the people, property or elements within the hazard zones that are prone to potential damages or losses (the element at risk) (UNISDR, 2009b).

\section{Flood Hazards Modeling and Mapping}

Mapping and prediction of flood hazards are important aspect of flood risk assessment. Flood nature, intensity and frequency of occurrence are better understood through mapping and simulating of both the already occurred and potential flood hazards. They are essentially useful for assessment of the level of risk (knowing the affected people and properties), providing early warning in case of future reoccurrence and hydraulic design, especially for potential flood management and disaster risk reduction. Although little researches have been conducted in this area based on the existing literatures, some Nigerian scholars have however conducted researches on the flood mapping in Nigeria, with most of them using remote sensing data aided by the Geographic Information Systems (GIS).

Ojigi et al. (2013) delineated and mapped 2012 flood in some parts of Central Nigeria (Niger-Benue-Kogi). The flood extent of the event was mapped using a combination of RADARSAT, Infoterra SAR, SPOT-5 imageries, Shuttle Radar Topography Mission (SRTM) DTM) with field information provided during the flood. Spatial analysis such as buffer was used to categorize the flood hazard extent using GIS and GPS data. In another study, Haruna et al. (2013) made use of hydrological model by simulating the effects of climate change on a Kaduna river. An open source model called Hydrognomon was used for the hydrological data processing with future climatic data. The results displays the expected river discharge for each climate change scenarios. Still on Kaduna river, Jeb and Aggarwal (2008) utilized remote sensing and GIS, Digital Elevation Model (DEM) integrated with flood stage data results from Gumbel's Extreme distribution model to estimate the extent of flood inundations in different flood return periods in Kaduna Metropolis. With this model, flood area extent was delineated and classified to different classes of risk. The usefulness of remote sensing and GIS in the assessment of flood hazards as reflected in the study undertaken by Rose et al. (2014) who employed Remote Sensing (RS) and Geographic Information System (GIS) techniques to carry out flood hazard assessment for the flood prone areas within the low-lying flat river valley of the River Dep watershed for 2-year to 1000-year using flood inundation maps previously obtained by Daffi (2013). The map was overlain on the settlement map of the study area to view those that will be affected by flood of these return periods. It was also overlaid on the Landsat land use classified map to view and analyse the land uses that would be inundated by the floods. In the same vein, Abah (2013) also applies Geographic Information Systems (GIS) in mapping flood risk zones in Makurdi Town. In the study, he draws its relevance from the importance of a GIS database in tackling flood related problems and creates a map of flood risk zones in Makurdi town. The ArcView GIS package was used to digitize a topographic map and other relevant themes of the study area. Through GIS overlay and manipulative functions, a Digital Elevation Model of the study area; and a classification map of flood risk zones in Makurdi town were created. The map of flood risk zones generated shows that Makurdi town is generally susceptible to flooding and very little has been done in steering away development from 'highly susceptible' areas. The capability of geo-information techniques has been demonstrated by Mayomi et al. (2013) in assessing the 2012 floods incidence that swept the communities along the coastal areas of Nigeria as well as those along the valleys of the major rivers in the country. In the study, vulnerability was classified into four: Highly vulnerable, vulnerable, marginally vulnerable and not vulnerable. The study found that all the 120 communities in the area were described as vulnerable to flood, that is, they were either highly vulnerable, vulnerable or marginally vulnerable. A digression was made by Ezemonye and Emeribe (2014) by utilizing statistical techniques to examine Disaster Risk Reduction (DRR) in the light of household preparedness in Benin City, Nigeria. The ANOVA test showed that there is a significant difference among households in terms of their flood disaster preparedness. A multiple correlation analysis indicated that religious belief and lack of funds determined household preparedness as these two variables explain the highest variance in the socio economic factors influencing utilization of flood disaster preparedness measures. More emphasis is continued to be placed on the relevance and suitability of geoinformation techniques in flood risk assessment as shown in Ogwuche and Abah (2014) work in which remotely sensed data have been utilized; focusing on the risk vulnerability of residential areas in parts of Makurdi floodplain, Benue State, Nigeria. The data were 
processed to produce a topographic map and digital elevation model. The study carried out overlay operation to produce the level of flood risk vulnerability for the residential areas as well as the catchment areas. The result showed that the highest catchment area of $22.01 \%$ fell within the moderate risk zone affecting Gaadi, Wurukum and Logo while the least of $4.15 \%$ was for the low risk zone affecting part of Lobi. Further studies such as Ismail and Saanyol (2013) employed remote sensing and GIS to produce flood map of the Middle Course of River Kaduna. The study considered the Middle Course of the river due to its very large area which passes through Kaduna metropolis and its potential to cause devastating effect to communities around the basin in the event of flood disaster. Digital Elevation Model was developed from high resolution imagery to identify flood prone areas along the Middle Course of the river. In the study, a flow accumulation model was created using the DEM and the DEM was reclassified into high risk, moderate risk and low risk zones using equal interval of separation based on elevation. This was overlaid on the map of the area to produce a vulnerability map of the area. Adeaga (2009) used GIS techniques to produce flood probability map and landuse/landcover pattern information of part of Lagos NE region, which was used to estimate flood risk and probable peak discharge of the different landuse/landcover classes. The study integrated these information into a GIS decision support system to provide a detailed flood pre-disaster and lead time geo-information services within the city. Aderoju et al. (2014) used remote sensing and GIS to assess, map and analyze the 2012 flood disaster in Kogi state, Nigeria for an effective flood disaster risk management and proper planning. Satellites imageries [MODIS of 20th October, 2008 (before) and 13th October 2012 (during) and provided by NASA; Nigeria Sat-X of 2012 and SPOT 5 of 2002], Base map of Kogi State, SRTM DEM, GPS coordinates; and flood pictorial evidence acquired during field survey were integrated to map flood plain, analyze the spatial extent of inundation and disaster risk areas.

\section{Exposure and Vulnerability Analysis}

Hazards occurrences do not necessarily lead to disaster until there are vulnerable exposed elements. Exposures, which are elements (tangible and intangible) at risk need to be quantified in risk assessment in order to understand their vulnerability and the impacts of hazards. In Nigeria, during most floods, many elements such as human, houses, cars, farms, businesses are often affected with monetary loss running to millions of dollars. Generally, after flood survey carried out by the Nigerian Environmental Agency (NEMA) accounts for the total number of exposed elements and their economic damages during any flood disaster (NEMA); these are presented to the government and international agencies for recovery and possible reconstruction. In the existing literatures most times, both exposure and vulnerability are integrated in risk analysis. Understanding the level and the degree of susceptibility of the exposures to flood hazards help in effective flood risk analysis. Although the meaning and the concepts of vulnerability is being contested by researchers, it remains an essential element in analyzing risk and also providing adaptation measures against disaster (Birkmann, 2013). Vulnerability and its various dimensions of measurements (i.e., physical, social, environmental and economic) are dynamic, with change in time and space and depends on the level of exposures and the potential hazards. With the issue of climate change in view, extreme hazards events and the continuous growing exposures through urbanization are expected to increase the level of vulnerability in many cities on the world, Nigeria inclusive (IPCC, 2014).

Quite a number of research works have been carried out in Nigeria in assessing the exposures and vulnerability of the Nigerian settlements to flooding. Onwuteaka (2014) applied GIS and digital elevation model to simulate extent of flooding exposure in the coastal areas and the vulnerability to sea level rise. At the varying sea elevation scenarios of $1,2,3,4,5$ and 13 meters, the expected surface area capable of being impacted by flood were identified for the modelled flooding from the sea level rise. Nwilo et al. (2012) assessed the physical vulnerability of some communities in Adamawa State, Northern part of Nigeria by modelling the flood inundation level using Remote Sensing and Cellular Automaton Evolutionary Slope And River (CAESAR) software. The output of the model shows the water heights and possible settlements at risk within the flood prone areas of the inundation. Hence, an attempt to examine the physical vulnerability of the communities was further analyzed by Ikusemoran et al. (2013) using Geographic Information Systems (GIS). Their study made use of Global Positional Systems (GPS) measurement to map all the settlements and integrated with the terrain model of the area to determine those areas that are within the flood plain. Vulnerability of some coastal communities in Lagos was examined by Adelekan (2009) using both quantitative and qualitative methods by analyzing data acquired from questionnaires, interviews and focus group discussion. The study also analyzed the impacts of and vulnerability to flooding within the coastal communities based on their level of income. The results asserted that most affected people in the area are the non-employed and less income people. In an attempt to assess the vulnerability of the exposures to flood within Ala river basin in Nigeria. Vulnerability of the affected villages and towns during 2012 flood was mapped by Ojigi et al. (2013) using remote sensing and GIS. Flood extent and the vulnerable cities and villages were identified using buffering techniques. A non- 
parametric approach to delineate floodplain in Gwagwalada town was adopted by Oyatayo et al. (2014) using topographic data, quick bird imagery and GPS data. Level of vulnerability of the town was determined and classified by the elevation in metreabove sea level (m.a.s.l), which revealed a gradual build-up into the floodplain area of the town. Oyinloye et al. (2013) made use of GIS coupled with questionnaires to understand the level of flood susceptibility of the people and properties in the area. Remote sensing data was used to delineate the river and buffering technique was applied to determine the watershed and possible flood plains. It covered that the percentage of the respondents from administered questionnaires accounted for those that were affected by the flood event. Their study also recommended structural measures such as construction of levee and walls along the river for protecting vulnerable exposures. The study carried out by Enaruvbe and Yesuf (2012) in Delta State, as part of flood risk analysis following the devastating 2012 flood event, made use of GIS and ASTER DEM to delineate the floodplain based on field survey in the affected areas. Flood affected and vulnerable zones were mapped using buffering tools in GIS environment. Geospatial techniques were applied by Nkeki et al. (2013) to map vulnerable zones within Niger-Benue basin. MODIS time series image, integrated with the digital elevation model were used to extract the flood plain within the basin. Various cities, states and communities that are vulnerable to flood hazards were mapped using population data; this was integrated with the flood hazards map to delineate the population at risk of flood disaster in the basin using overlay analysis. In Samagba area of Bayelsa State, Mmom and Akpi (2004) determined the vulnerability of the communities to flooding using elevation and remote sensing image data. Analytical Hierarchical Process (AHP) was adopted to assign weights to various contributory factors such as elevation, land use, rivers and roads to determine the most vulnerable zones within the area; these were integrated using re-classification and overlay analysis in GIS to determine the flood affected areas. Analysis done by Ejenma et al. (2014) over
Kaduna river utilized DEM to delineate flow accumulation of the rivers; this was assumed to be the floodplain and classified to various degrees of severity and overlaid on Lands at ETM+ to delineate vulnerable areas within the area.

In contrast to the qualitative physical vulnerability studies by the earlier authors, Ajibade et al. (2013) examined the socio-economic impacts of flash flood on women in Nigeria using Lagos State as a case study. The authors utilized both questionnaires and focused group survey to understand the impacts of flood on lives, livelihoods and health. Their results revealed a nongender biased impacts, however, a more severe impacts recorded within low-income neighbourhood than those in high income neighbourhood. A post July, 2007 flood survey carried out by Adelekan (2011) to examine the vulnerability of the urban dwellers in Abeokuta, OgunState in terms of their awareness and preparation for such events. The study, which made use of responses of the administered questionnaires showed a general lack of early warning systems in the study area and affirmed the high risk to flooding due to lack of pre-flood information and preparation. Vulnerable and exposed population to flooding in River Ogun, Ogun-State were analyzed by Sobowale and Oyedepo (2013) by modelling rain-runoff to generate flood inundation model. The study identified over 1.4 million inhabitants that were at risk in the area, with suggested possible adaptation measures for future occurrences.

Studies on exposure and vulnerability to flooding in Nigeria is still at infant stage and would require more advanced studies to bridge the gap that exists, especially when compared with the developed countries. Table 2 showed the summary of the vulnerability analysis as done by some authors in Nigeria. Most of the reviewed works have concentrated on the qualitative assessment of the physical vulnerability of the people and properties to flooding by using flood hazards map, zoning and buffering within certain distance to rivers; whereas, quantitative assessment of the physical vulnerability is still lacking in the literatures.

Table 1. Some case studies on flood mapping in Nigeria

\begin{tabular}{|c|c|c|c|}
\hline Major Outputs & Methods & Study Area & References \\
\hline Flood hazard extent & GIS and Remote Sensing & Niger-Benue-Kogi & Ojigi et al. (2013) \\
\hline Flood hazard extent & GIS and Remote Sensing & River Kaduna & Ismail and Saanyol (2013) \\
\hline Flood hazard extent & GIS and Remote Sensing & Kogi state & Aderoju et al. (2014) \\
\hline $\begin{array}{l}\text { Flood probability map, } \\
\text { probable peak discharge }\end{array}$ & GIS and Remote Sensing & Lagos & Adeaga (2009) \\
\hline $\begin{array}{l}\text { River discharge for each } \\
\text { climate change scenarios }\end{array}$ & Hydrological modeling, & RiverKaduna & Haruna et al. (2013) \\
\hline Inundation model & $\begin{array}{l}\text { Remote sensing and GIS, digital } \\
\text { elevation model (DEM), flood discharge }\end{array}$ & Kaduna Metropolis & Jeb and Aggarwal (2008) \\
\hline Flood risk zones & GIS and Remote Sensing & Markurdi & Abah (2013) \\
\hline Flood plain map & GIS and Remote Sensing & & Aderoju et al. (2014) \\
\hline
\end{tabular}


Table 2. Some case studies on flood vulnerability in Nigeria

\begin{tabular}{llll}
\hline Types of vulnerability & Methods & Study area & References \\
\hline Qualitative physical vulnerability & GIS and Remote Sensing & Gwagwalada town & Oyatayo et al. $(2014)$ \\
Qualitative physical vulnerability & GIS & Adamawa & Ikusemoran et al. $(2013)$ \\
Qualitative physical vulnerability & Questionnaires, GIS & Akure & Oyinloye et al. $(2013)$ \\
Socio-economic vulnerability & Questionnaires survey & Lagos & Ajibade et al. (2013) \\
Awareness, qualitative physical vulnerability & Questionnaires survey & Abeokuta & Adelekan (2011) \\
Social and Qualitative physical vulnerability & Run-off modeling & River Ogun & Sobowale and Oyedepo (2013) \\
Qualitative physical vulnerability & GIS and Remote Sensing & Niger-Benue-Kogi & Ojigi et al. $(2013)$ \\
Qualitative physical vulnerability & Remote Sensing & Niger-Benue basin & Nkeki et al. $(2013)$ \\
Qualitative physical vulnerability & Flood modeling, Remote Sensing & Adamawa & Nwilo et al. $(2012)$ \\
Qualitative physical vulnerability & Remote Sensing and GIS & Bayelsa & Mmom and Akpi (2004) \\
\hline
\end{tabular}

\section{Discussion}

The generality of the research works concentrate on the determination of the flood extent by buffering around the river and/or using satellites imageries of the said flood dates to determine the flood risk level and extents (Ejenma et al., 2014; Enaruvbe and Yesuf, 2012; Nkeki et al., 2013) (see Table 1). While it is absolutely important to apply remote sensing data and GIS tools, certain fundamental principles in hydrological modeling and prediction has not been incorporated into flood simulation and mapping in the country. Flood mapping by means of only GIS generally belongs to flood model group called 0Dimensional models; these models lack basic physical laws and cannot be regarded as simulation. This method, which is predominant in most studies in the country utilizes a Digital Terrain Model (DTM), overlaid on pre-determined high flood water level. The distance between the water level and the terrain (surface) elevation is assumed to be the flood or inundation depth. Although, this seems a logical idea in deriving flood extent and depths, it however lacks basic governing hydrological principles and physical laws. Certain hydrological and physical components such as rainfall, infiltration, channel flows, evaporation, nature of soil, roughness, hydraulics etc., which determines the propagation of flood waves cannot be incorporated in such a model.

Several numerical and distributed models and packages (MIKE Flood, Flo 2D, HecRAS, CaMa-Flood, City Cat, HASUS-MH, ISIS, SWMM, STORM, MOUSE and HEC-HMS, NK-SHER), which incorporates the fundamentals of hydrology and water volume conservation for flood simulations are available in many countries (Bates and De Roo, 2000; Dutta et al., 2003; Dutta and Nakayama, 2009; Flo-2D, 2009; NKT, 2011; Yin et al., 2015); these are capable of calculating rainfall runoff and modeling urban flood inundation with some degree of accuracy. None of these have been effectively utilized to estimate the flood inundation level in the country, which undermine the accuracy of the previous mappings. Due to the uncoordinated urban growth, poor and complex river systems, high level vulnerability of the communities and lack of river prevention and management in Nigeria and its communities, it is rather important to incorporate many boundary conditions for effective understanding of flood hazards and the intensity of their occurrences. This would definitely extend beyond just the use of remote sensing and GIS, but will incorporate other spatial data inputs. In order to enhance understanding of the flood hazards for effective risk assessment and management, estimation and simulation of flood events will not only determine the extent of flooding, but also basic characteristic of flood (e.g. water depths, velocity, duration, sediments, wind etc.) that accounts for the degree of damages and devastations encountered during flooding.

The use of stage damage function as being adopted for quantitative assessment of both physical and economic vulnerability by most developed countries is yet to be studied within local and national organizations. Stage-damage function, also called vulnerability, fragility or loss function is used to carry out flood damage estimation; an important part of flood risk analysis and future disaster risk reduction. Knowing future economic losses from a particular flood events helps in effective planning for proactive disaster risk reduction. Stage-damage function was first developed in 1960s by the United States of America (White, 1964) followed by the British (Penning-Rowsell and Chatterton, 1979), Australia (Smith and Greeaway, 1988) and Japan (Dutta and Herath, 2001; Dutta and Nakayama, 2009; MOC, 1996). Some other researchers have developed various methodologies for loss and damage estimation (Chormanski et al., 2011; Dutta et al., 2003; Herath and Wang, 2009; James and Hall, 1986; Jonkman et al., 2008; Salimi et al., 2008; Su et al., 2005; Tapia-Silva et al., 2011) using different methods. Stage damage curves established for particular countries are used for rapid estimation of potential or expected damages from a flood event (Herath et al., 1999). Loss function is mostly expressed in as a function of flood characteristics such as flood depths, wind, velocity, duration and sediments.

Most scholars in the flood risk studies in the country have not included the potential influence of 
climate change on the future extreme events and their accompanied losses and damages. Effective flood management in the country would require knowledge about the potential or expected damages/losses, since most risk management are based on cost benefit analysis. Researches covering the measurement and assessment of vulnerability of various damage categories (tangible and non-tangible) are yet to be carried out despite the past and the present flood challenges in the countries; this is an essential components of risk assessments needed by the government, risk insurance companies and ministries for planning, mitigating and adapting to future flood events. Assessment of already occurred and potential flood damages for planning and recovery has been given much attention in many developed countries such as USA (White, 1964) United kingdom (PenningRowsell and Chatterton, 1979), Australia (Smith and Greeaway, 1988) and Japan (Dutta and Herath, 2001; Dutta and Nakayama, 2009; MOC, 1996).

Flood damage estimation makes use of flood damage curve, also known as fragility or vulnerability curves to estimate/predict the expected flood damages. Flood damage curves establishes the relationship between the degree of flood damages to various flood damage categories and flood characteristics (e.g., water depth, duration, wind, sediments, velocity etc.); from the established relationship, a function or model for each damage categories can be established which is used for simulating flood damages for different return scenarios. Flood damage is generally classified into two categories: The intangible and tangible damages. Tangible damages according to Dutta et al. (2003) and Herath et al. (1999) is expressed in monetary value and are divided into two: Direct and indirect damages. The direct are flood damages caused by direct contact with the flood while the indirect damages are damages that are not directly connected to the flood water. Flood damage curves can be developed in two ways: Empirical and synthetic methods. The earlier is based on the flood survey while the latter is dependent on the expert judgment and administration of questionnaires in the past flood affected areas. Generally, flood damage or loss estimations start with flood plain mapping and modeling; this is mostly carried out using hydrological models to obtain inundation characteristics (distributions of flood depths above ground, velocity and duration) (Bormudoi et al., 2011; de Moel et al., 2012; Dutta et al., 2003; Heisten and Davdge, 2005; James and Hall, 1986; Messner and Meyer, 2006). The flood hazard is then integrated with the degree of loss (stage-damage function) and the economic value of the element at risk to determine the total risk or loss (Cammerer et al., 2013).
It is obvious from the literatures that there are no existing model for assessing flood risk in the country, especially flood damage estimation. With the present change in climate and the subsequent consequences, there is need for both government and non-governmental agencies, including researchers that are involve in flood disaster preparedness to know the importance of vulnerability assessment in predicting future and expected outcome of impending disaster; establishing these models nationally will go a long way to assist in mitigating, adapting and preparing for future flood. Climate change would increase the occurrence and the intensities of the future weather, which might result into extreme events with greater damages than what was experienced before. This would require a proactive measure to assess the potential economic risk considering the present adaptation measure in the country; this would enable investment in to risk planning and mitigation against future extreme events.

Environmental aspect of vulnerability is yet to gain full attention. The susceptibility of the people to the environmental consequences of flood such as water pollution, which may results into unhealthy life is yet to be fully carried out. The impact of flooding on water quality and human health is grievous, especially in the rural communities, which solely depends on river water for living because there is no access to clean water.

\section{Conclusion}

This work has shown that several studies have been carried out on the flood vulnerability and risk assessment in different parts of the country. Most of these studies focus on the social-economic and physical qualitative vulnerability aspects of flood hazards. The use of GIS and Remote sensing alone to map flood events are not enough to adequately measure the intensity and the extent of flood and its impacts. Further research on the use of the state of the art flood models available across countries, some of which are open source are necessary to improve the flood risk analysis in the country.

Prospective view of future climatic condition in relation to the possible future hazards is very important in assessing the flood risk and preparing for mitigation and adaptation measure. Flood modeling should hence incorporate the effect of climate change, based on climate change scenarios for extreme events to understand the risk associated with various river basins in the country. Attention should be given to climate downscaling using either statistical or dynamic methods.

The environmental aspect of vulnerability of flood hazard has suffered a serious neglect. In addition, the review has revealed that there is no proper 
coordination of research activities in respect of flood hazard risk and vulnerability assessment in Nigeria and hence most of the research findings have not been synchronized at national scale to really evolve a flood action plan for the country. Consequential to this, the country has not been able to evolve a model at country level which can be used to estimate flood damages and predict future occurrences and losses. Further research is recommended in this direction.

\section{Author's Contributions}

Initial research concept was designed by A.A. Komolafe, Literature review; findings and final draft of the manuscript were jointly done by all the Authors.

\section{Ethics}

All the Authors read and approved the manuscript and no ethical issues involved.

\section{References}

Abah, R.C., 2013. An application of geographic information system in mapping flood risk zones in a north central city in Nigeria. Int. J. Water Resources Environ. Eng., 7: 365-377.

Adeaga, O., 2009. Planning and warning tools for flood disaster management in Lagos Mega city. Proceedings of the 5th Urban Research Symposium Lagos, (RSL' 09)002E

Adegbola, A.A. and J.K. Jolayemi, 2012, Historical rainfall-runoff modeling of river Ogunpa, Ibadan, Nigeria. Ind. J. Sci. Technol., 5: 2725-2728. DOI: $10.17485 / \mathrm{ijst} / 2012 / \mathrm{v} 5 \mathrm{i} 5 / 30450$

Adelekan, I., 2011. Vulnerability assessment of an urban flood in Nigeria: Abeokuta flood 2007. Natural Hazards, 56: 215-231. DOI: $10.1007 / \mathrm{s} 11069-010-9564-\mathrm{z}$

Adelekan, O.I., 2009. Vulnerability of poor urban coastal communities to climate change in Lagos, Nigeria. Proceedings of the 5th Urban Research Symposium, Jun. 28-30, World Bank, Marseille, France.

Aderogba, K.A., 2012. Qualitative studies of recent floods and sustainable growth and development of cities and towns in Nigeria. Int. J. Basic Applied Sci., 1: 200-216.

Aderoju, O.M., J. Jantiku, O.A. Fagbemiro, I. Aliyu and B.K. Nwadike et al., 2014. Geospatial assessment of 2012 flood disaster in Kogi State, Nigeria. J. Environ. Sci. Toxicol. Food Technol., 8: 74 -84.

Agbola, B., O. Ajayi, O. Taiwo and B. Wahab, 2012. The August 2011 flood in Ibadan, Nigeria: Anthropogenic causes and consequences. Int. J. Disaster Risk Sci., 3: 207-217. DOI: $10.1007 / \mathrm{s} 13753-012-0021-3$
Ajibade, I., G. McBean and R. Bezner-Kerr, 2013. Urban flooding in Lagos, Nigeria: Patterns of vulnerability and resilience among women. Global Environ. Change, 23: 1714-1725.

DOI: 10.1016/j.gloenvcha.2013.08.009

Alexander, D., 2000. Confronting Catastrophe: New Perspectives on Natural Disasters. 1st Edn., Oxford University Press, New York, ISBN-10: 0195216962 , pp: 282.

Bates, P.D. and A.P.J. De Roo, 2000. A simple rasterbased model for flood inundation simulation. J. Hydrol., 236: 54-77. DOI: $10.1016 / \mathrm{S} 0022-1694(00) 00278-\mathrm{X}$

Birkmann, J., 2013. Measuring Vulnerability to Promote Disaster-Resilient Societies and Enhance Adaptation: Discussion of Conceptual Frameworks and Definitions. In: Measuring Vulnerability to Natural Hazards: Towards Disaster Resilient Societies, Birkmann, J. (Ed.), New York, United Nations University Press, ISBN-13: 9789280812022, pp: 9-54.

Bormudoi, A., J.S.M. Fowze, M.K. Hazarika, L. Samarakoon and K. Gunasekara et al., 2011. Rapid flood damage estimation: A case study at Chandpur, Bangladesh. Proceedings of the 3rd International Conference on Water and Flood Management, (WFM' 11), At Dhaka, Bangladesh.

Bubeck, P., H. de Moel, L.M. Bouwer and J.C.J.H. Aerts, 2011. How reliable are projections of future flood damage? Nat. Hazards Earth Syst. Sci., 11: 3293-3306. DOI: 10.5194/nhess-11-3293-2011

Cammerer, H., A.H. Thieken and J. Lammel, 2013. Adaptability and transferability of flood loss functions in residential areas. Nat. Hazards Earth Syst. Sci., 13: 3063-3081.

DOI: $10.5194 /$ nhess-13-3063-2013

Chormanski, J., T. Okruszko, S. Ignar, O. Batelaan and K.T. Rebel et al., 2011. Flood mapping with remote sensing and hydrochemistry: A new method to distinguish the origin of flood water during floods. Ecol. Eng., 37: 1334-1349.

DOI: $10.1016 /$ j.ecoleng.2011.03.016

Daffi, R.E., 2013. Flood hazard assessment for river DEP catchment using remote sensing and geographic information system techniques. $\mathrm{PhD}$ Thesis, Ahmadu Bello University Zaria.

de Moel, H., N.E.M. Asselman and J.C.J.H. Aerts, 2012, Uncertainty and sensitivity analysis of coastal flood damage estimates in the west of the Netherlands. Nat. Hazards Earth Syst. Sci., 12: 1045-1058. DOI: $10.5194 /$ nhess-12-1045-2012

Dutta, D. and S. Herath, 2001. GIS based flood loss estimation modeling in Japan. Proceedings of the US-Japan 1st Workshop on Comparative Study on Urban Disaster Management, (UDM' 01), Port Island, Kobe, Japan. 
Dutta, D., S. Herath and K. Musiake, 2003. A mathematical model for flood loss estimation. J. Hydrol., 277: 24-49.

DOI: $10.1016 / \mathrm{S} 0022-1694(03) 00084-2$

Dutta, D. and K. Nakayama, 2009. Effects of spatial grid resolution on river flow and surface inundation simulation by physically based distributed modelling approach. Hydrol. Processes, 23: 534-545. DOI: $10.1002 /$ hyp.7183

Dutta, D., W. Wright, K. Nakayama and Y. Sugawara, 2013. Design of synthetic impact response functions for flood vulnerability assessment under climate change conditions: Case studies in two selected coastal zones in Australia and Japan. Natural Hazards Rev., 14: 52-65.

DOI: 10.1061/(ASCE)NH.1527-6996.0000085

Editor, G., 2012. Taming the floods in Lagos. The Guardian.

Ejenma, E., V.N. Sunday, O. Okeke, A.N. Eluwah and I.S. Onwuchekwa, 2014. Mapping flood vulnerability arising from land use/land covers change along river Kaduna, Kaduna State, Nigeria. IOSR J. Humanities Soc. Sci., 19: 155-160.

Enaruvbe, G.O. and G.U. Yesuf, 2012. Spatial analysis of flood disaster in Delta State, Nigeria. IFE Res. Public. Geography, 11: 52-58.

Ezemonye, M.N. and C.N. Emeribe, 2014. Flooding and household preparedness in Benin City, Nigeria. Mediterranean J. Soc. Sci., 5: 547 -553. DOI: $10.5901 / \mathrm{mjss} .2014 . v 5 n 1 \mathrm{p} 547$

Flo-2D, 2009. Flo-2D Reference manual. FLO-2D Software, I., ed.: Nutrioso.

Guha-Sapir, D., P. Hoyois and R. Below, 2013. Annual disaster review 2012: The numbers and trends. Centre for Research on the Epidemiology of Disasters (CRED), Institute of Health and Society (IRSS), Universite catholique de louvain-Brussels, Belgium.

Haruna, G., I. Abubakar, I. Abdullahi, A. Saminu and F. Bayang, 2013. Hydrological modeling of the impact of climate change on a tropical perennial river flooding. Int. J. Eng. Sci., 3: 30-35.

Heisten, M. and D. Davdge, 2005. Flood damage estimation in the upper themes river Watershed. University of Western Ontario and University of Waterloo.

Herath, S., D. Dutta and K. Musiake, 1999. Flood damage estimation of an urban catchment using remote sensing and GIS. Proceedings of the International Conference on Urban Storm Drainage, (UCD' 99), pp: 2177-2185.

Herath, S. and Y. Wang, 2009. Incorporating wind damage in potential flood loss estimation. Global Environmental Research.

Hewitt, K., 1980. Book review: The environment as hazard. Annals Assoc. Am. Geographers, 70: 306-311.
Ikusemoran, M., D. Anthony and U.M. Maryah, 2013. GIS based assessment of flood risk and vulnerability of communities in the Benue floodplains, Adamawa State, Nigeria. J. Geography Geol., 5: 148-160. DOI: $10.5539 /$ jgg.v5n4p148

Mayomi, I., A. Dami and U.M. Maryah, 2013. GIS based assessment of flood risk and vulnerability of communities in the Benue floodplains, Adamawa State, Nigeria. J. Geography Geol., 5: 148-160. DOI: $10.5539 /$ jgg.v5n4p 148

IPCC, 2014. Climate Change 2014: Impacts, Adaptation and Vulnerability. IPCC Working Group II Contribution to AR5. Summary for Policymakers. Intergovernmental Panel for Climate Change.

Ismail, M. and I.O. Saanyol, 2013. Application of Remote Sensing (RS) and Geographic Information Systems (GIS) in flood vulnerability mapping: Case study of River Kaduna. Int. J. Geomat. Geosci., 3: 618-627.

James, L. and B. Hall, 1986, Risk information for floodplain management. J. Water Resources Plann. Manage., 112: 485-499.

DOI: 10.1061/(ASCE)0733-9496(1986)112:4(485)

Jeb, D.N. and S.P. Aggarwal, 2008, Flood inundation hazard modelling of the river Kaduna Using remote sensing and geographic information systems. J. Applied Sci. Res., 4: 1822-1833.

Jonkman, S.N., M. Bočkarjova, M. Kok and P. Bernardini, 2008. Integrated hydrodynamic and economic modelling of flood damage in the Netherlands. Ecol. Econom., 66: 77-90.

DOI: $10.1016 /$ j.ecolecon.2007.12.022

Ke, Q., S.N. Jonkman, T. Rijcken and P.V. Gelder, 2012. Flood damage estimate for downtown shanghai citysensitivity analysis. Proceedings of the Poster Presentation, the 3rd Conference of the International Society for Integrated Disaster Risk Management, Sept. 7-9, Beijing, China.

Komolafe, A.A., S.A.A. Adegboyega, A.Y.B. Anifowose, F.O. Akinluyi and D.R. Awoniran, 2014, Air pollution and climate change in Lagos, Nigeria: Needs for proactive approaches to risk management and adaptation. Am. J. Environ. Sci., 10: 412-423. DOI: 10.3844/ajessp.2014.412.423

Messner, F. and V. Meyer, 2006. Flood Damage, Vulnerability and Risk Perception-Challenges for Flood Damage Research. In: Flood Risk Management: Hazards, Vulnerability and Mitigation Measures, Schanze, J., E. Zeman and J. Marsalek (Eds.), Springer Netherlands, ISBN-10: 1402045964, pp: 149-167.

Mmom, P.C. and A. Akpi, 2004. Spatial analysis of flood vulnerability levels in Sagbama Local Government Area using Geographic Information Systems (GIS). Int. J. Res. Environ. Stud., 1: 1-8. 
MOC, 1996. Flood damage statistics in Japan. Technical Report, River Engineering Bureau, Ministry of Constructio, Japan.

Nkeki, F.N., P.J. Henah and V.N. Ojeh, 2013. Geospatial techniques for the assessment and analysis of flood risk along the Niger-Benue Basin in Nigeria. J. Geographic Inform. Syst., 5: 123-135. DOI: 10.4236/jgis.2013.52013

NKT, 2011. Nippon Koei Technical Report on NKGIAS.

Nwilo, C.P., D.N. Olayinka and E.A. Adzandeh, 2012. Flood modelling and vulnerability assessment of settlements in the Adamawa state floodplain using GIS and cellular framework approach. Global J. Human Social Sci., 12: 10-20.

Ogwuche, J.A. and I.A. Abah, 2014. Assessment of flood disaster vulnerability for flood insurance programme in part of Makurdi floodplain, Benue State, Nigeria. Donnish J. Ecol. Nat. Environ., 1: 001-005.

Ojigi, M.L., F.I. Abdulkadir and M.O. Aderoju, 2013. Geospatial mapping and analysis of the 2012 flood disaster in central parts of Nigeria. Proceedings of the 8th National GIS Symposium, Apr. 15-17, Dammam, Saudi Arabia.

Onwuteaka, J., 2014. GIS modeling of flooding exposure in Nigerian coastal areas from sea level rise. J. Environ. Earth Sci., 4: 81-94.

Oyatayo, K.T., J. Uwazuruonye, A. Andesikuteb, H. Tata and E.S. Abimiku et al., 2014. Non parametric modeling of flood vulnerability: For sustainable growth and development of Gwagwalada, Federal Capital Territory, Nigeria. J. Environ. Sci. Policy Evaluat., 4: 15-23.

Oyinloye, M.A., O.I. Olamiju and S.O. Babalola, 2013. Combating flood crisis using GIS: Empirical evidences from ala river floodplain, Isikan Area, Akure, Ondo State, Nigeria. Commun. Inform. Sci. Manage. Eng., 3: 439-447.

Penning-Rowsell, E.C. and J.B. Chatterton, 1979. The Benefits of Flood Alleviation: A Manual of Assessment Techniques. 1st Edn., Gower Technical Press, UK.

Rose, E.D., A.O. Johnson and I. Abubakar, 2014. Flood hazard assessment of river DEP floodplains in North-Central Nigeria. Int. J. Water Resources Environ. Eng., 6: 67-72. DOI: $10.5897 /$ IJWREE2013.0457
Salimi, S., M.R. Ghanbarpour, K. Solaimani and M.Z. Ahmadi, 2008. Floodplain mapping using hydraulic simulation model in GIS. J. Applied Sci., 8: 660-665.

Smith, D.I. and M. Greeaway, 1988. Floohe computer assessment of urban flood damage: ANUFLOOD. Technical Report, Desktop Planning, Melborne, Australia.

Sobowale, A. and J.A. Oyedepo, 2013. Status of flood vulnerability area in an ungauged basin, southwest Nigeria. Int. J. Agric. Biol. Eng., 6: 28-36.

Su, M.D., J.L. Kang, L.F. Chang and A.S. Chen, 2005. A grid-based GIS approach to regional flood damage assessment. J. Marine Sci. Technol., 13: 184-192.

Tapia-Silva, F.O., S. Itzerott, S. Foerster, B. Kuhlmann and H. Kreibich, 2011. Estimation of flood losses to agricultural crops using remote sensing. Phys. Chem. Earth Parts A/B/C, 36: 253-265. DOI: $10.1016 /$ j.pce.2011.03.005

UNCHA, 2012. Floods Situation Report, UN Office for the Coordination of Humanitarian Affairs, v. 2.

UNISDR, 2009a. Risk and Power in a Chnaging Climate: Invest today for a safer tomorrow. United Nations International Strategy for Disaster Reduction (UNIDR).

UNISDR, 2009b. Terminology on Disaster Risk Reduction (DRR). Geneva, Switzerland., UNISDR.

UNISDR, 2013a. Global assessment report on disaster risk reduction: From shared risk to shared value: the business case for disaster risk reduction. Unuted Nations office of Disaster Risk Reduction (UNISDR).

UNISDR, 2013b. Loss Data and Extensive/Intensive Risk Analysis. United Nations Office of Disaster Risk Reduction (NUIDR).

White, G.F., 1964. Choice of Adjustment to Floods. Research paper, Department of Geography, University of Chicago.

White, P., M. Pelling, K. Sen, D. Seddon and S. Russell et al., 2005. Disaster risk reduction. A Development Concern. DFID.

Yin, J., M. Ye, Z. Yin and S. Xu, 2015. A review of advances in urban flood risk analysis over China. Stochastic Environ. Res. Risk Assessment, 29: 1063-1070. DOI: 10.1007/s00477-014-0939-7 